\title{
Movement from emerging economies to small island states: motivations of Nigerian educational tourists in North Cyprus
}

\author{
Cahit Ezel
}

Faculty of Tourism, Eastern Mediterranean University, Famagusta, North Cyprus

cahit.ezel@emu.edu.tr

\section{Huseyin Arasli}

Faculty of Tourism, Eastern Mediterranean University, Famagusta, North Cyprus

huseyin.arasli@emu.edu.tr

\begin{abstract}
Although core countries, in particular the UK, USA, Canada, and Australia, have been the most popular destinations for educational tourism, a substantial number of educational tourists have recently been travelling to other European, Asian, and African countries. There has been significant research into student mobility from developing countries to core countries, but research on student mobility between developing countries - in particular the movement from emerging economies to small island states-is scarce. North Cyprus has recently become a thriving international educational tourism destination. This study explores the factors affecting educational tourists' decision-making, with a specific focus on Nigerian students, about whom very little is known regarding their decision to study abroad and their choices of host country and host university. Data from a qualitative study carried out in the small island state of North Cyprus is used to examine the factors that push Nigerian educational tourists away from their home country to seek tertiary education opportunities elsewhere as well as the factors affecting their host country and host institution choices. Three main themes emerged from the data analysis, namely: Studying Overseas, Country Choice, and Host Institution. The results of this study are useful for policymakers in small island states, who wish to establish or improve an educational tourism industry, as well as for university decision-makers who wish to increase their institutions' success at attracting foreign students.
\end{abstract}

Keywords: educational tourism, educational tourists, Nigeria, North Cyprus, small island states, universities

https://doi.org/10.24043/isj.87 • Received December 2018, accepted May 2019

C 2019-Institute of Island Studies, University of Prince Edward Island, Canada.

\section{Introduction}

In the past decade, educational tourism has attracted the attention of researchers (Chen, 2008; Daily, Farewell, \& Kumar, 2010; Eder, Smith, \& Pitts, 2010; Lam, Ariffin, \& Ahmad, 2011; Maringe \& Carter, 2007; Pyvis \& Chapman, 2007; Wilkins et al., 2012) from various disciplines such as marketing, educational leadership and management, tourism, business, and international 
education. Although educational tourism can take different forms, such as conferences, language courses, and training programs, formal tertiary education is the most common and rapidly progressing form of educational tourism. International students, edu-tourists, and overseas students are other terms frequently used in the literature to refer to the same phenomenon. In this paper, the term educational tourist is used to encompass all international students who travel abroad, with their experience in the host country characterising a core element of their education. Such a definition includes exchange programs, language schools, university/college courses, and full university/college degree programs (Ritchie, 2003).

The number of students studying outside their home countries doubled from 2.5 million in 2007 (UNESCO, 2009) to a staggering 5 million in 2014 (ICEF, 2015), and estimates suggest this trend is likely to continue and reach 8 million by 2025 (OECD, 2012). This is "encouraged in part by the economic, political and social forces of globalization" (Wilkins \& Huisman, 2011, p. 61). Moreover, an increasing number of educational tourists regard travelling abroad for tertiary education as an opportunity for cultural enrichment, developing foreign language skills, obtaining high-status qualifications, and gaining access to better jobs (OECD, 2013).

Emerging economies such as China, India, South Korea, Turkey, Malaysia, Nigeria, and Kazakhstan have recently come to occupy the top of the student-exporting countries league (BC\&OE, 2012). Moreover, there is a growing trend for prospective students from emerging economies to enter the academic systems of developed countries (such as the USA, UK, Australia, Canada, Germany, France, Japan, Russia, and China) (BC\&OE, 2012). Englishspeaking destinations such as the USA, UK, Australia, and Canada have been among the most popular host countries, and research has focused on student mobility from China, Malaysia, India, and Africa to countries in which the higher education sector is very well developed and English is either the native language or widely spoken. However, research into student mobility between developing countries, particularly the movement of educational tourists from emerging economies to small island states, remains limited and represents a significant gap in our understanding of the push-and-pull factors that influence the decisions of educational tourists.

This paper contributes to filling this gap by focusing on Nigerian educational tourists who are currently enrolled at a university in North Cyprus. More specifically, this research aims to answer the following research questions:

(1) Which factors influence Nigerian educational tourists' decisions regarding studying abroad?

(2) Which factors influence Nigerian educational tourists' decisions regarding the choice of a host country?

(3) Which factors influence Nigerian educational tourists' decisions regarding the choice of a host university?

There has been a steady flow of educational tourists from Nigeria to North Cyprus, particularly in the past decade, yet the factors affecting Nigerian educational tourists' decisions have not been thoroughly studied. Because policymakers lack proper understanding of these factors, they end up making ad hoc decisions based on 'guesses' rather than 'facts'. 


\section{Literature review}

The nature of education as a service

Educational services are distinguished from other services in many respects. Because "most of the quality attributes in higher education cannot be perceived, felt or tested in advance" (Cubillo et al., 2006, p. 3), the decision to study abroad is a difficult process for educational tourists. The decision involves serious considerations regarding diverse factors, such as departing one's home country for a period of time, financial implications of studying abroad, and socioeconomic life in the host country. This decision carries relatively greater risks because educational tourists must travel to the place where the service is produced and consumed at the point of production, in many cases a completely unfamiliar environment. Additionally, because educational tourists have diverse expectations, it is difficult, if not impossible, to provide a standardized service. Meeting varied expectations becomes even more complex given that prospective students purchase a bundle of different services alongside the education service (Cubillo et al., 2006). It is not uncommon for educational tourists to compare a number of alternative host countries and host institutions before reaching a final decision. Over the years, models have been developed to explain international students' decisionmaking processes. These can be categorised as economic, status attainment, and combined models, each of which seeks to develop our understanding of how students endeavour to satisfy their needs for higher education and thereby rationalise what was once considered an irrational and inexplicable aspect of human behaviour (Vrontis et al., 2007). The most notable of these is the push-pull model based on Lee's (1966) theory of migration, which was developed by McMahon (1992) and further advanced by Mazzarol and Soutar (2002).

\section{Educational tourist decision-making model}

The push-pull model has three stages. In Stage 1, the prospective educational tourist makes a choice of studying internationally or studying locally, a choice that is influenced by a number of push factors operating within the home country (Wilkins \& Huisman, 2011). Push factors can be diverse, and they influence prospective students in various ways. The most common push factors involve the economic, environmental, and/or political situation (Maringe \& Carter, 2007) in the home country. Poor economic conditions, political instability, violation of human rights, systematic corruption, or lack of democratic rights at home country may spur a student to seek options overseas. Prospective students may envisage studying abroad as an opportunity to get away from poor conditions in the home country and live in a relatively better setting, at least for a period of time. In contrast, students from developed countries in which political, social, and economic life is relatively much better also travel overseas for tertiary education. Economic development produces a need for qualified people: studying abroad and being educated in certain subjects that are not taught locally can provide excellent opportunities for educational tourists to find well-paid and secure employment. Familial influence (Pimpa, 2004) is another key push factor. In some cultures, for example in Asia (Yang, 2007), families play an influential role in encouraging students to travel overseas. Push factors can also be related to the higher education system and the state of local universities (Mazzarol \& Soutar, 2012). Local higher education systems may lack the capacity to absorb demand, and certain academic programs may be unavailable at local universities. Moreover, students may deem the quality of education at local universities unsatisfactory. Another push 
factor is the desire to gain familiarity with new cultures, learn new languages, and feel more integrated with the world (Bhati \& Anderson, 2012).

Once prospective students decide to study abroad, they move on to Stage 2 of the process, in which the host country is selected. This decision is influenced by a number of pull factors at the host country which make host country relatively more attractive to students (Mazzarol \& Soutar, 2002). Mazzarol and Soutar (2002) argue that factors such as knowledge of and awareness about the host country; recommendations from peers and family members; cost issues such as living expenses, travel costs, and social costs; environmental issues such as host country lifestyle and safety issues; geographical proximity of host country to home country; and social links such as family and friends residing in host country influence the host country choice of educational tourists. In other words, "it is the perceived offerings of a particular country, its resources, its reputation, its facilities, and so on that attract students to enrol in their universities" (Nachatar Singh et al., 2014, p. 6). Particularly after 9/11, it has become a formidable challenge for students from the Middle East, Africa, and some Asian countries to get a visa to many Western countries (Mughal, 2016). As a result, students from these regions have moved towards countries with relatively relaxed visa regimes. The reputation of the host country as a higher education hub in the international arena, coupled with the reputation of the local universities, may also act as an encouraging factor. Moreover, for educational tourists who travel overseas for tertiary education, part-time job opportunities (Barron \& Anastasiadou, 2009; Kwadzo, 2014) in the host country can be attractive. Possibilities of migrating to the host country can also act as an encouraging factor, particularly for some students from emerging economies who are keen to start new lives in the West.

In Stage 3, the educational tourist is expected to choose a specific host institution. Pull factors are institution specific. Host institution choice is influenced by factors such as "institutional reputation, international recognition of qualification, teaching quality and locational factors" (Maringe \& Carter, 2007, p. 463). Factors students consider when selecting a host university may also include availability of certain programs, academic reputation, campus atmosphere, quality of the teaching staff, and type of university (Soutar \& Turner, 2002). However, not all factors carry equal weight: "students consider what is important to them and, consciously or unconsciously trade-off between these attributes" (Soutar \& Turner, 2002, p. 40).

\section{Educational tourism in North Cyprus}

Educational tourism is a major industry in North Cyprus, which has a population of around 326,000 and a land area of $3355 \mathrm{~km}^{2}$. Due in part to the territorial conflict regarding the northern part of the Mediterranean island of Cyprus, North Cyprus has limited export opportunities, particularly beyond exports to Turkey. This makes educational tourism a significant source of foreign exchange for North Cyprus.

Higher education in North Cyprus dates back to the late 1970s. Currently, North Cyprus is home to 17 universities, with further applications to open new universities pending approval (Mertkan, 2018). The student population, which is predominantly of Turkish and Turkish Cypriot origin, has recently been changing. In the 2016-2017 academic year, over 93,000 students were enrolled at North Cyprus universities, with around 27,500 international students (excluding those from Turkey) from more than 100 different countries representing 30\% of the total student population. Turkish students currently enrolled in North Cyprus universities 
constitute the majority of students but are not regarded as international students. The international students category consists primarily of students from African, Middle Eastern, and Central Asian countries such as Nigeria (26.7\%), Pakistan (8.6\%), Iran (7.2\%), Syria (6.4\%), Jordan (5.2\%), Iraq (4.6\%), Libya (4.4\%), Zimbabwe (4.3\%), Palestine (3.7\%), Azerbaijan (3.1\%), Kazakhstan (2.2\%), Turkmenistan (1.7\%), Egypt (1.5\%), Cameroon (1.4\%), Lebanon (1.4\%), Congo (1.2\%), Kyrgyzstan (1.1\%), Russia (1.0\%), and Somalia (1.0\%) (TCYHB, 2015). On the basis of the above, Nigerian educational tourists constitute far and away the largest group of educational tourists not only at any particular host university but in North Cyprus in general, thereby making Nigerian educational tourists an important topic of inquiry.

Table 1: Student population of North Cyprus universities. Sources: SPO (2016) \& MNEC (2018).

\begin{tabular}{llllll}
\hline & $2012-13$ & $2013-14$ & $2014-15$ & $2015-16$ & $2016-17$ \\
\hline Turkish Cypriot & 10,995 & 12,658 & 12,026 & 13,706 & 13,619 \\
& $21.0 \%$ & $20.2 \%$ & $16.2 \%$ & $16.2 \%$ & $14.6 \%$ \\
Turkish & 31,152 & 34,828 & 41,928 & 46,937 & 52,135 \\
& $59.6 \%$ & $55.6 \%$ & $56.6 \%$ & $55.5 \%$ & $55.9 \%$ \\
International & 10,160 & 15,210 & 20,138 & 23,918 & 27,538 \\
& $19.4 \%$ & $24.3 \%$ & $27.2 \%$ & $28.3 \%$ & $29.5 \%$ \\
Total & 52,307 & 62,696 & 74,092 & 84,561 & 93,292 \\
\hline
\end{tabular}

\section{Methodology}

A qualitative research approach was adopted to gain in-depth understanding of the factors influencing educational tourists' decisions regarding studying abroad, host country choice, and host institution choice. To gain a thorough understanding of the students' decision processes, face-to-face, semi-structured, in-depth interviews were conducted with undergraduate Nigerian educational tourists at Eastern Mediterranean University (EMU), located in Famagusta, North Cyprus. Each interview lasted around 30-40 minutes. Semistructured interviews were conducted since they provide a more flexible structure for the researcher to comprehensively probe the factors affecting students' decisions (Dawson, 2002).

Purposive sampling was identified as the most appropriate method of selecting respondents. The sample size was determined on the basis of the concept of saturation: the saturation point is reached when additional interviews no longer yield new data on the issues under investigation (Mason, 2010). Although the saturation point was reached at 12 respondents, research continued, and a total of 11 male and 9 female Nigerian students enrolled at different undergraduate programs were interviewed.

Conducting qualitative research requires incorporating certain strategies to augment the credibility of the study during research design and implementation (Noble \& Smith, 2015). In this research, the strategies recommended by Noble and Smith (2015) were followed to improve the study's trustworthiness, rigour, and quality. The American Educational Research Association Code of Ethics (AERA, 2011) was strictly followed throughout the research process. Respondents were asked to participate in the research on a voluntary basis and sign a consent form. Prior to the interview, respondents were appropriately informed about the survey's intentions and how survey responses would be utilised. Respondents were assured that all information would be kept confidential and that anonymity would be strictly obeyed. Moreover, approval of the Academic Research Ethics Committee at EMU had been obtained prior to initiating the research. 
Thematic analysis, which is a method of identifying, analysing, and interpreting patterns of meaning ('themes') within qualitative data (Clarke \& Braun, 2017) was employed. According to Braun and Clarke (2006), the thematic analysis method has the advantage of being a flexible research tool that provides rich, detailed, and complex accounts of data because of its theoretical freedom. The six-phase thematic analysis process recommended by Braun and Clarke (2006) was used to create established and meaningful patterns. A bottom-up approach was utilised during the data analysis process. The interview transcripts were read several times to gain familiarity with the data and to generate codes. Related codes were then brought together to generate categories and finally data-driven themes emerged. Qualitative data analysis software (ATLAS.ti) was utilised to analyse the interview transcripts, conduct the coding process, and organise the data extracts.

Consequently, the following main themes emerged from the data analysis: (a) Studying Overseas (Home Country Push Factors), (b) Country Choice (Host Country Pull Factors), (c) Host Institution Choice (Institutional Pull Factors).

\section{Studying overseas: home country push factors}

The decision to study locally or internationally is influenced by push factors originating from within the home country (Mazzarol \& Soutar, 2002). Our research identified four groups of factors that influence the decision of Nigerian educational tourists regarding overseas education.

\section{Family and peer influence}

As the following interview excerpt demonstrates, nuclear family members such as mother, father, and siblings play an influential role in the Nigerian educational tourists' decisions:

[My father] already had this plan that we not schooling in Nigeria. I asked him why because Nigeria education was really, really not suitable for you. If you want to accomplish a lot you need to go out. (JII-Male)

This is unsurprising, given the prevalence of the patriarchal family system in Nigeria (Dogo, 2014), where the father has a dominant role as the main opinion leader, whose decisions meet little resistance from other family members.

Peers and other family members such as uncles, aunts, and cousins also have an influencethough not as strong as nuclear family members—on the prospective educational tourists' decisions:

First and foremost, the decision of leaving the country to study outside was not my idea initially. It was my uncle's talk that brought the idea to me. (IAD-Male)

The influential role of family on international education decisions is not peculiar to Nigeria. Thai students' choices of international education, for example, are also influenced by family members (Pimpa, 2004). Similar findings have also been identified in Australia (Shanka et al., 2006).

\section{Problems in the local higher education system}

The research identified certain problems in the local higher education system that pushed Nigerian educational tourists to seek higher education options elsewhere. One of the most striking problems is limited access to local universities: 
We have this format where, once you are done with college you have this exam called JAMB. So you write it and when you pass it you need to get a score before you could even apply for a university of your choice. So if you do not get that actual score or the corner mark of the university you do not get to even apply for university directly. So it was like a barrier so to say. [...] If you do not get messed up by the JAMB you get messed up by the university, if you do not get messed up by the university and the JAMB maybe you get to hear that maybe you name got to come out from the list of the university, maybe because there was too much people on the list for the applicants. (IAD-Male)

With a population of nearly 186 million people, Nigeria is the seventh-most populous country in the world (WENR, 2018). Around 35 million people in Nigeria fall into the 1524 age group, and 82 million people are 14 years old or younger (UNESCO, 2018). The rapidly growing and young population places a formidable burden on the higher education system in Nigeria, where proper state support for capacity building is insufficient. In 2015, two-thirds of the students who sat for the national university entrance exam could not gain admission to local universities (WENR, 2018), not to mention gain admission to the particular programs they wish to study.

Students who are denied admission to federal or state universities alternatively seek a place in local private universities (Ajadi, 2010). However, private higher education in Nigeria has not yet reached to the capacity to absorb the surplus student population. The first private university in Nigeria was established in 1979, and since then private universities have been established by individuals, businesses, and religiously affiliated establishments (Olawore \& Ajayi, 2016). Although establishment of private universities has had a positive impact on the Nigerian higher education system by providing alternatives for students, the research identifies a number of problems that deter many Nigerians from enrolling in private universities.

There are private universities, but the things they teach there and the finance, it's not worth it, so it's better for him to take his child abroad than to take him to a private university in Nigeria. Because I think they pay almost certain same amount as here, and the kind of lecturers they have in private universities they are corrupt, there are lecturers where students can bribe and pay money to pass exam. (ATU-Male)

Private universities in Nigeria are not only expensive but also restrictive in nature. Most are affiliated with religious groups and enforce strict rules regarding student behaviour, dress codes, and freedom of movement, which discourage many students. Moreover, respondents report that educational quality is little if at all better than many overseas universities. Students thus prefer to obtain an overseas degree, which is more prestigious in Nigerian society and will enable them to find a 'good' job. Our research findings in this respect accord with those of the comprehensive study carried out by Ajadi (2010).

Another factor that pushes Nigerian educational tourists overseas is the tough education system at local universities. Students are obliged to take a heavy course load, which can prove difficult for even industrious students: 
You are taking a course, but you take other courses that do not even go with whatever you are studying in general. Here we take six courses per semester; in Nigeria you could take 13 courses per semester so you can see that some courses there are not actually needed but you just have to do it. (SSA-Female)

Taking an excessive number of courses, coupled with the problem of frequent and long-lasting strikes at local universities, causes serious delays in delivering education. Frequent strikes by academic and non-academic staff have had an adverse impact on the provision of education services, have lowered education quality, and have reduced trust in the higher education system.

The federal and also state universities and some polytechnics, they do go for national strikes. Once gone for strike, it takes them, like, six months or maybe a year to resolve the matter. (AGO-Female)

For example, in 2013, strikes disrupted delivery of education for over five months at 60 public universities across Nigeria, and a similar situation occurred in 2016 at ten federal and state universities (WENR, 2018). Moreover, strikes have a detrimental effect on completion of study within a reasonable time period. In Nigeria, in most academic disciplines in the sciences, humanities, and social sciences, the standard undergraduate program lasts four years (WENR, 2018), yet our research indicates that even the most hard-working students struggle to complete their studies within this timeframe.

Local degrees furthermore hold low prestige among public and private sector employers as well as members of society in Nigeria:

In Nigeria is that getting jobs is very hard and studying outside is kind of an extra plus for you. [...] They believe you have more knowledge and, like, this system is better. (HES-Female)

Consequently, prospective students who have access to finance and other means take the opportunity to pursue higher education at overseas.

Problems at local higher education institutions

Problems prevailing at local universities constitute a third group of push factors. One of these issues is the classroom environment:

Schooling in Nigeria is more tedious and difficult because it is not like here you have the right to ask questions. Here they are really concerned about if you understand or not, but in Nigeria it is not like they don't care but the population is so much there in class you don't even get contact your lecturer. (JCU-Female)

Nigerian federal and state universities struggle with over-enrolment. Coupled with insufficient government funding, this leads to serious problems regarding availability of physical resources, infrastructure, and education quality (Fabiyi \& Uzoka, 2009). A lack of properly equipped and spacious classrooms causes serious discomfort for both present and prospective students. 
Corruption is also a formidable problem in Nigerian universities. The research identifies institutionalised corruption, with prospective students needing to bribe certain administrators at universities to enrol in university or in a specific academic program. Bribing lecturers to get a passing grade is also a common practice:

Before you can get an admission you either bribe a lecturer or you bribe a head of department or whoever is working in that department. [...] Sometimes you can be given like the admission but it will be what you cannot study. I don't know how they do it, but they can just give you any course to study, which I think is inappropriate, and if you want a course of your choice, you have to bribe someone. [...] In Nigeria, talk about exams or quiz, like, if you fail your exams, you meet a lecturer he either ask for money or if you are lady they ask for sex. But here it is just different; you cannot even compare. (RV-Female)

A comprehensive study carried out by Nwaokugha and Ezeugwu (2017) reported that corruption in Nigeria is a common practice in everyday life. Inevitably, the Nigerian higher education system has been contaminated by this social disease. The limited choice of academic programs is also problematic, particularly at federal and state universities, with the result that many students are unable to enrol in the programs they wish to study.

Another major issue reported by the respondents is cultism at Nigerian universities. This can have serious implications for current and prospective students:

They have cults, and it is very strong. I have been in Cyprus studying here and I have not observed this at all, but over in Nigeria they are very strong. Even the academic staffs are part of the cults too. (AO-Male)

Cults on Nigerian campuses represent a serious social and security-related problem, with impacts on not only Nigerian higher education but society as a whole (Arhedo et al., 2011). Because of conflicts between cults, some students who are already enrolled in a program drop out and leave the country to pursue tertiary education elsewhere.

Quality of education at local universities is another issue concerning prospective students:

Teaching is very bad, it's very poor. Sometimes they bring in courses that you not meant to take. They will just bring it for a reason, and they will not explain it or teach you properly so you have to do all that by yourself. Most time the teachers do not even come to class throughout the week, and that's when they tell you if you want to pass then you have to do what I am telling you to do, and they will make you take the course carry over in the next semester. (IEO-Male)

Quality of education problems are mostly related to a lack of proper physical facilities and infrastructure (Fabiyi \& Uzoka, 2009). Another striking finding from the research concerns the impact that bad attitude from lecturers can have on students:

Sometimes a teacher might not like you, so you might keep on doing one course for so many years. The teacher wouldn't just let you pass. And then our classes, 
like a course could have 800 students, but the class could only take 200 students, so you might not be able to get it, and some teachers just don't, what we are being taught in class is very different from what comes out from exam. (SSA-Female)

\section{Personal reasons}

The research identified that personal reasons also influence the decision regarding studying abroad. Personal factors such as frustration with the home country and seeing studying overseas as an opportunity to have a different life encourage prospective educational tourists to look for opportunities elsewhere:

I wanted a better life. I don't know, like, I wanted to change of environment because all my life I been there, so I wanted to change of environment. I wanted to meet new people, make new friends, see different people from different countries and get to know their way of life, their language, their culture everything. (MI-Female)

According to respondents, prospective students see themselves as confined in Nigeria and see studying overseas as an opportunity to meet new people, learn new cultures and languages, and develop an international network.

\section{Host country choice: host country pull factors}

Once an educational tourist decides to study overseas, the next step, which is influenced by pull factors, is to decide on a host country. Our research identified five main categories of host country pull factors.

\section{Access}

Access basically refers to the degree of readiness and willingness to choose a particular destination as a host country. Educational tourists select a particular country either because it is the only choice available to them given their financial and academic background or because they are willing to take the first available option given their degree of desperation and limited timeframe. One respondent reports:

You know most people come here, they go to agents; they give them options. I did everything myself. [...] What I just had in my mind is just to leave and that was like only option I had then. That was made me actually to come. (JCU-Female)

The researches identifies that most of the Nigerian educational tourists who come to North Cyprus would have been unable to access other countries and were simply desperate to enrol at an overseas university. Because of the light bureaucratic system, easy admission processes at North Cyprus universities, and relatively simple visa processes compared to many Western countries, North Cyprus becomes a lifesaver.

\section{Cultural factors}

Cultural factors such as diversity of population in terms of nationality and richness of cultural 
and historical heritage are also identified as influential factors. Respondents report that:

My grandmother went for pilgrimage, this Christianity pilgrimage and all, and North Cyprus has some Christian historical places [...] I was so excited, I was happy that I was coming to a safe place, to a religious place. (SO-Male)

I rather come here than go to Mauritius or South Africa, which are African countries basically, and going far East Asia or South Asia, where I believed at the time that the people here will speak more English, and it will be easier for me to relate with people here than over there. (SOD-Male)

As stated above, having educational tourists from over 100 different countries has turned North Cyprus into a very attractive place for those who would like to study in an international environment, learn about new cultures, and learn new languages. Moreover, in some cases, historical heritage of the host country and popularity of English language usage among locals can also act as a pull factor.

\section{Environmental factors}

Environmental characteristics of the host country can also be an important factor in attracting educational tourists who have certain expectations. One of these factors is the quietness of North Cyprus and its safe environment:

It is better than the UK, USA because sometimes I drive, and police stop me, and I will even put my hand down, I am not scared of them which I find comfortable. In USA, one friend of mine said you should raise your hands when police stop you, or I should be scared for my life. All those things is why people bring their kids here because it is safer, and there is no cult issues like other countries, and there is no like other countries cult related, too much party, drugs you know. Cyprus is controlling everything, which makes it great. (JIO-Male)

Lack of discrimination against nationality, colour, and gender makes North Cyprus an attractive place, particularly for people with certain sensitivities. Another issue that makes North Cyprus' universities attractive is the lack of conflicts among cults. Despite the large population of Nigerian educational tourists, no cult-related disputes have thus far been reported to North Cyprus' security services.

\section{Financial factors}

Research identifies that financial factors have a strong influence on educational tourists' decisions since many of them are travelling from emerging economies and have limited financial resources. What matters here is the cost of universities in the host country relative to the costs of universities in the home country and in other potential host countries:

I considered USA and then Canada and the UK, but my mom said that she had heard about Cyprus from other people, and it was as good as USA. And she was 
like, why would I pay so much when I could same quality of education here, so she advised that I come here. (SSA-Female)

Costs of living and all other related costs such as accommodation, travel, healthcare, and other miscellaneous expenses are found to influence the decisions of Nigerian educational tourists, particularly those who are on a tight budget and rely heavily on self-finance.

\section{Plans for the future}

Educational tourists who are considering migrating to Western countries but are denied access because of the tight visa regimes of some destination countries envisage North Cyprus as a stepping stone:

I saw it as an opportunity to go to another country because for me it is a lot of easier to get into another country from another country not from your own country. Because from your own country, it is kind of difficult. (PIA-Male)

Nigerians who seek visas to Western countries have to go through difficult and lengthy visa application processes, and in many cases their applications are turned down after they have already spent a considerable amount of time and money. There is a general impression among respondents that if they study in North Cyprus, it will be relatively easier for them to obtain visas to Western countries either to pursue their studies or to migrate.

\section{Influence of others}

Last but not least, the research identifies three key players who play influential roles in Nigerian educational tourists' decisions. One of the key players is student recruitment agents in Nigeria, which promote universities for a commission fee. These agents are the key mentor for the educational tourists and are seen as a trustworthy reference:

I had an agent who did everything for me. Actually, I wanted to go UK, and he brought the idea of North Cyprus. [...] It was not something in my mind. I didn't know about the country. So he was the one that said, "OK Canada is expensive, UK is expensive. What about Cyprus?” (MI-Female)

Family and peer influence are also found to have a strong impact on the decision-making process. It was interesting to find that families prefer to send their children to countries where they have acquaintances, simply because they feel that their children will be in safe hands and that there will be assistance available in the host country in case it is needed.

Really, it was only Cyprus I considered because my sister, also my brother was here doing his $\mathrm{PhD}$. So it was the only country I was able to consider because they were here, so I was like since they are here it would be nice, having their family here. (AO-Male) 


\section{Host institution choice: institutional pull factors}

The final part of the research focused on identifying the factors affecting host institution choice. Theoretically speaking, the decision of host country choice is followed by the choice of host institution, which is influenced by a number of institution-specific factors (Cubillo et al., 2006; Daily et al., 2010; Maringe, 2006). In general, the educational tourist evaluates a number of institutions from different perspectives and makes a final decision about one. In some instances, however, educational tourists make a choice without considering the alternatives. Our research identified six main categories of institutional pull factors.

\section{Academic factors}

The most important academic factors seriously considered by the Nigerian educational tourists are the attitudes of lecturers, accreditation of degrees offered by accreditation agencies or similar institutions, affiliations with other reputable universities, university rankings, range of academic programs, university reputation, and teaching quality.

In Nigeria for you to even have access to your lecturer; you have to be exceptional in class. The lecturer needs to know, "OK he is a good student; he is not just someone who is trying to get access to me." [...] We have never been this free. I can just come into your office and sit and talk. In Nigeria, it doesn't work like that. There is this type of, like I said, big classroom, hundreds of students, and the lecturer is carrying a megaphone or something. But here the maximum in a class is not even up to 50 . The lecturer wants to know the name of every student in his or her class. It's something different. (SOD-Male)

Because based on the ranking then, and based on a lot of things that we Africans always check it, the school ranking and the way the school is recognised. Eastern Mediterranean University is one of the recognised school here. So I know definitely I would apply here, there is no choice I have to be here. (JII-Male)

Prospective students gather information about the host university through peers and relatives who are already enrolled at the host university. They also gather information through other means, such as student recruitment agents and online resources such as university websites, blogs, and social media.

Academic factors are not limited to accreditation, affiliation, and rankings. As reported by a respondent, availability of diverse academic programs and having access to the program of your choice is also a major issue:

Here you apply for courses, and you get that course you want. No one is going to twist it or do anything. I knew people in Nigeria, they had to do corruption and stuff to be able to do what they wanted. Coming to Cyprus, I knew this is what I wanted to do, and I am going to focus on what I want to do. (AO-Male)

Teaching quality and university reputation are other issues that are seriously considered. The quality of teaching cannot be evaluated directly by the educational tourist before enrolling in 
a program, but information can be gathered from trustworthy peers, current students, and reports available online.

My friends were making comparison that [university name removed] is actually much cheaper than here and but Eastern Mediterranean University has high standard of education than [university name removed]. So for me that was it. If Eastern Mediterranean University is better in terms of academics, then I don't care about the money. (RV-Female)

\section{Admissions}

The admissions process at EMU is found to have an influence on decisions regarding the choice of host institution.

I came here because I first got the admission before the rest of the schools I applied. [...] I applied for a school in Canada, and I also applied to a school in Ukraine, but I got here first. (JII-Male)

The admissions process can be quite tedious at some overseas universities. Tough admissions requirements, coupled with challenging visa processes, may cause serious delays, which can be a particularly big problem for educational tourists who do not wish to or cannot wait. Universities that have less bureaucracy and have a speedy admissions process become viable options for educational tourists who are in a rush to depart from their home country.

\section{Financial factors}

Unless additional financial support such as scholarships or grants are secured, prospective students from relatively less-wealthy families have little or no opportunity to study abroad. As one respondent reports:

Well, like I said, I already had a family member here in, but regardless of that, the proposal we had for international students that you get a $50 \%$ scholarship, and the fact that when you get here and your grades are well to do, you can actually get a full scholarship. (IAD-Male)

Educational tourists need to evaluate the costs and benefits (Prakhov, 2016) of making an investment in tertiary education prior to their decision. Tuition fees, living expenses, and other expenses can reach unaffordable levels for some prospective educational tourists. Provision of scholarships and similar types of financial assistance is attractive to Nigerian educational tourists who, generally speaking, are on a tight budget and have difficulty finding part-time jobs to support their studies.

\section{Influence of others}

The research also reveals that Nigerian educational tourists' decisions regarding choice of host institution is influenced family members and student recruitment agents, as is the case for decisions regarding studying overseas and host country choice. One respondent reports: 
I did not actually choose it myself. When I was done with my high school, I was having up issues getting admission to one of the universities. So my family member suggested to go out and check out the website of Eastern Mediterranean University. That is how I found out that there was a school like that outside. Secondly my cousin was actually here so it was easy for me. (AGO-Female)

It was found that Nigerian families prefer to send their children to a host university where a family member or close trustworthy acquaintance is already studying. They feel that their children will be safe and taken care of in case of emergency. Student recruitment agents nevertheless play an important role in guiding prospective educational tourists. In some cases, certain student recruitment agents represent more than one North Cyprus university but will promote a specific university that grants them a higher commission or with which they have a better relationship. If the recruitment agent happens to be a graduate of that particular university, it usually makes him or her more convincing and better able to divert students to the university.

\section{Language}

In many non-English speaking countries, universities today offer academic programs in English as part of a strategy to attract international educational tourists. Using English as a medium of instruction also provides an opportunity to access the most recent academic work and thus has an impact on the quality of education:

Another thing is, because it is international school, everything is in English. [...] The reason why I came here was because in other countries, you have to study the language for a year before you start the program. (PIA-Male).

The medium of instruction at EMU is mostly English (certain programs are offered in Turkish as well), and because of student demographics, English is widely used both on campus and by locals. As a result, educational tourists do not need to learn the local language in order to complete programs and interact with society.

\section{Conclusions}

Over one-quarter (27\%) of educational tourists (TCYHB, 2015) in North Cyprus are Nigerians. This research aimed to study this particular cohort in order to gain an in-depth understanding of its choices regarding studying abroad, host country, and host university selection as well as to highlight some practical implications and develop recommendations for further research.

Based on the research findings, a push-pull model for Nigerian educational tourists is depicted (see Figure 1). One of the key findings of this research is that, in every country, economic, social, cultural, and political structure influence prospective students' decisions regarding overseas tertiary education. Since each country possesses different structures, each educational tourist-sending country needs to be evaluated on its own merits. Another important issue is that economic and political structures are not static and can be influenced by internal as well as global factors. Any sudden change in these factors could have various impacts on the factors that push prospective educational tourists away from their home countries. 
Figure 1: Pull-push model of Nigerian educational tourists in North Cyprus.

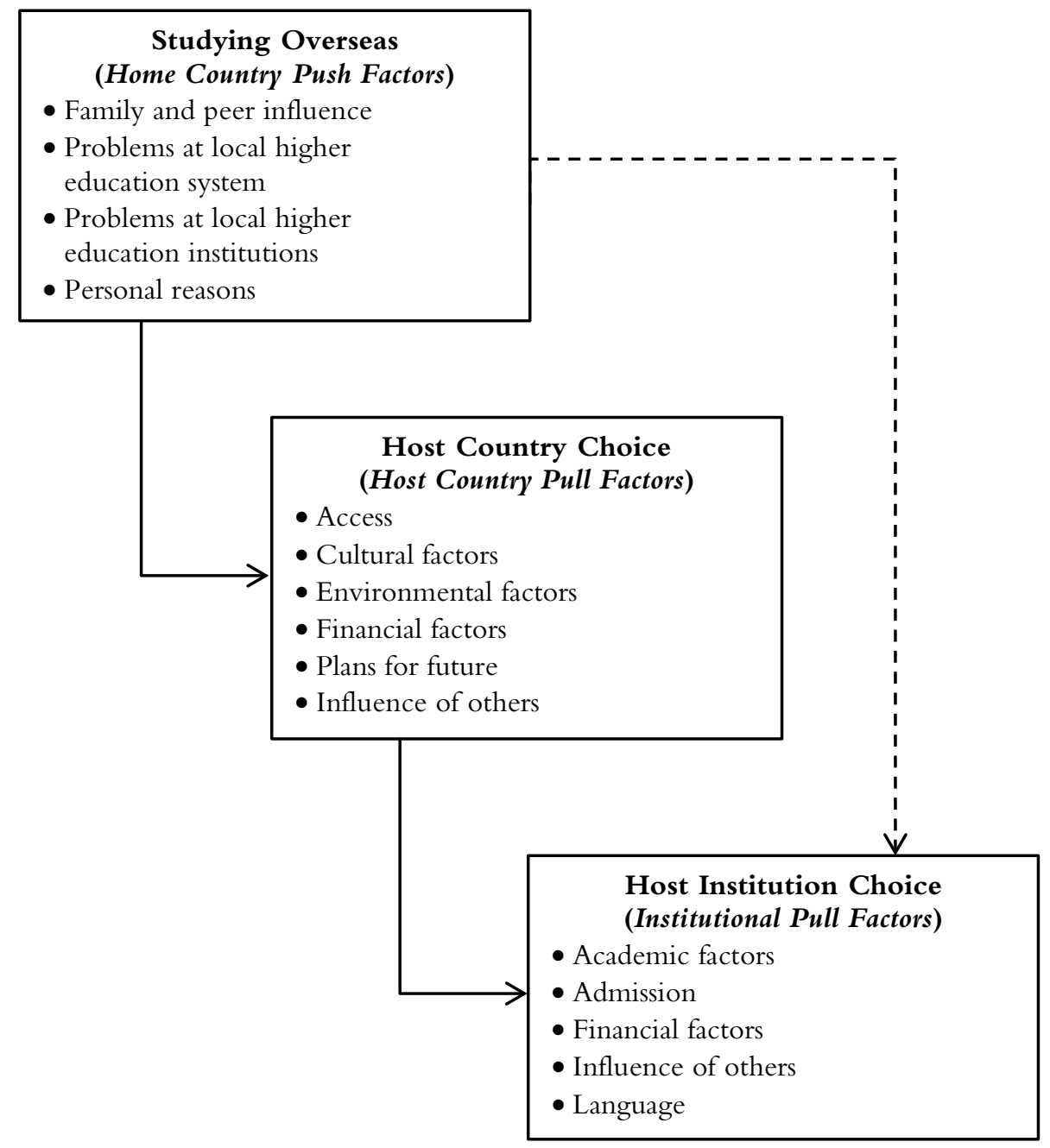

The research suggests that North Cyprus' educational tourism industry has benefited from political and economic processes that are only partly under the control of government policymakers and university decision-makers in North Cyprus. North Cyprus' status as a place simultaneously within and outside of Europe may prove problematic for other parts of the economy, but it has facilitated an educational tourism industry that possesses some of the cachet of Europe without many of the financial and legal restrictions of Europe, particularly in terms of visa regulations. The fact that North Cyprus and its universities in many cases seem to be an educational tourism destination of last resort for prospective Nigerian students means that an improvement in conditions for educational tourists within the rest of Europe, the USA, and other desirable host countries could damage the relative attractiveness of North Cyprus universities. It also means that North Cyprus policymakers and university administrators should be wary of drawing too strong of conclusions regarding their country's or institution's place image or brand.

Host country pull factors are also country specific. The important point here is to understand how well these factors can be matched with the expectations of prospective educational tourists. During the interviews, for example, some student respondents said that they came to North Cyprus because it is quiet, yet other student respondents complained that 
life in North Cyprus was too slow and that there was less to do there than in developed Western countries. Identifying the gap between the expectations of prospective educational tourists and the life and infrastructure of the host country is thus a formidable challenge that needs to be tackled by policymakers. Policymakers, particularly at the national level, need to incorporate these differences into their strategic plans. This requires serious research among the educational tourists as well as reporting and policy development at national and institutional levels.

In the final part of the research, the factors affecting educational tourists' decisions regarding host institution choice are elaborated. Unlike the home country push factors and host country pull factors, institutional pull factors are fully under the control of the university administrations. The findings can be directly utilised by the host university under consideration since each university in North Cyprus possesses its own unique characteristics therefore not claiming generalisation of the study. However, the findings can provide some hints to other universities about what may attract potential Nigerian educational tourists who are selecting a host institution. Moreover, the identified factors can be utilised to develop promotional programs particularly for the Nigerian market as well as to develop programs to further enhance student satisfaction among current Nigerian educational tourists.

The research identified another important issue regarding the decision-making process as a whole. As explained in the literature review, a prospective student first decides whether to pursue tertiary education at home or abroad. If the prospective student favours education abroad, the next stage is to select a host country and a host university among alternatives within the selected host country. In this research, the researcher found that some Nigerian educational tourists skip the second stage and end up applying to a university without considering the actual details, conditions, and location of North Cyprus as a host country. In other words, the students decide to study abroad, select a host university, and only then search for information about North Cyprus and collect information from various resources. We identify two factors behind this 'mixed-up' system of decision making. One factor is student recruitment agents, who guide the students to the host university, and since many Nigerian educational tourists are very keen to leave their home country, they frequently put little thought into where precisely their overseas host university is located. Another factor is the manner in which a host university gain a good reputation in Nigeria due to extensive promotional campaigns and its large alumni group. This raises awareness about the university among prospective educational tourists and their families, who play an important role in decision making.

One of the main contributions of this research is to fill a gap in the literature regarding Nigerian educational tourists. Nigeria is one of the largest student-exporting countries in Africa, yet there has been little research into why Nigerian educational tourists travel to other countries for tertiary education. One of the main shortcomings of this research is the sample of respondents was limited to one state trust university in North Cyprus. Selection of respondents from private universities in North Cyprus would provide grounds for comparison between universities with different ownership types, management models, and geographical locations. Moreover, expanding the respondents to educational tourists from other countries would provide better insight into why educational tourists choose to study in North Cyprus. 


\section{References}

AERA (2011). American Educational Research Association code of ethics. Educational Researcher, 40(3), 145-156. https://doi.org/10.3102/0013189x11410403

Ajadi, T.O. (2010). Private universities in Nigeria: the challenges ahead. American Journal of Scientific Research, 7, 15-24.

Arhedo, P.A., Aluede, O., \& Adomeh, I.O.C. (2011). Predictive factors in undergraduates' involvement in campus secret cults in public universities in Edo State of Nigeria. Research in Education, 85, 43-52. https://doi.org/10.7227/rie.85.4

Barron, P., \& Anastasiadou, C. (2009). Student part-time employment: implications, challenges and opportunities for higher education. International Journal of Contemporary Hospitality Management, 21(2), 140-153. https://doi.org/10.1108/09596110910935642

BC\&OE (2012). The shape of things to come: higher education global trends and emerging opportunities to 2020. London: British Council \& Oxford Economics.

Bhati, A., \& Anderson, R. (2012). Factors influencing Indian student's choice of overseas study. Procedia: Social and Behavioral Sciences, 46, 1706-1713. https://doi.org/10.1016/j.sbspro.2012.05.365

Braun, V., \& Clarke, V. (2006). Using thematic analysis in psychology. Qualitative Research in Psychology, 3(2), 77-101. https://doi.org/10.1191/1478088706qp063oa

Chen, L.H. (2008). Internationalization or international marketing? two frameworks for understanding international students' choice of Canadian universities. Journal of Marketing for Higher Education, 18(1), 1-33. https://doi.org/10.1080/08841240802100113

Clarke, V., \& Braun, V. (2017). Thematic analysis. Journal of Positive Psychology, 12(3), 297-298.

Cubillo, J.M., Sanchez, J., \& Cervino, J. (2006). International student's decision-making process. International Journal of Educational Management, 20(2), 101-115. https://doi.org/10.1108/09513540610646091

Daily, C.M., Farewell, S., \& Kumar, G. (2010). Factors influencing the university selection of international students. Academy of Educational Leadership Journal, 14(3), 59-75.

Dawson, C. (2002). Practical research methods: a user-friendly guide to mastering research techniques and projects. Oxford: How to Books.

Dogo, S.A. (2014). The Nigerian patriarchy: when and how. Cultural and Religious Studies, 2(5), 263-275.

Eder, J., Smith, W.W., \& Pitts, R.E. (2010). Exploring factors influencing student study abroad destination choice. Journal of Teaching in Travel \& Tourism, 10(3), 232-250. https://doi.org/10.1080/15313220.2010.503534

Fabiyi, A., \& Uzoka, N. (2009). State of physical facilities in Nigerian universities: implication for repositioning tertiary institutions for global competition. In J. Babalola, L. Popoola, A. Onuka, S. Oni, W. Olatokun, \& R. Agbonlahor (Eds) Proceedings of towards quality in African higher education (pp. 180-187). Higher Education Research and Policy Network. https://doi.org/10.4314/majohe.v4i1.7

ICEF (2015). The state of international student mobility in 2015. ICEF Monitor, 5 November. http://monitor.icef.com/2015/11/the-state-of-international-student-mobility-in-2015/

Kwadzo, M. (2014). International students' experience of studying and working at a northeastern public university in the US. Journal of International Students, 4(3), 279-291. 
Lam, J.M.S., Ariffin, A.A. M., \& Ahmad, A.H. (2011). Edutourism: exploring the push-pull factors in selecting a university. International Journal of Business and Society, 12(1), 63-78.

Lee, E.S. (1966). A theory of migration. Demography, 3(1), 47-57.

Maringe, F. (2006). University and course choice. The International Journal of Educational Management, 20(6), 466-479.

Maringe, F., \& Carter, S. (2007). International students' motivations for studying in UK HE: insights into the choice and decision making of African students. International Journal of Educational Management, 21(6), 459-475. https://doi.org/10.1108/09513540710780000

Mason, M. (2010). Sample size and saturation in $\mathrm{PhD}$ Studies using qualitative interviews. Forum Qualitative Sozialforschung/Forum: Qualitative Social Research, 11(3).

Mazzarol, T., \& Soutar, G.N. (2002). 'Push-pull' factors influencing international student destination choice. International Journal of Educational Management, 16(2), 82-90. https://doi.org/10.1108/09513540210418403

Mazzarol, T., \& Soutar, G.N. (2012). Revisiting the global market for higher education. Asia Pacific Journal of Marketing and Logistics, 24(5), 717-737. https://doi.org/10.1108/13555851211278079

McMahon, M.E. (1992). Higher education in a world market: an historical look at the global context of international study. Higher Education, 24(4), 465-482. https://doi.org/10.1007/bf00137243

Mertkan, S. (2018). Higher education systems and institutions, northern part of Cyprus. In P.N. Teixeria \& J.C. Shin (Eds) Encyclopedia of International Higher Educational Systems. Dordrecht: Springer. https://doi.org/10.1007/978-94-017-9553-1 430-1

MNEC (2018). 2017-2018 statistical yearbook. Nicosia: Ministry of National Education and Culture, Nicosia, Turkish Republic of Northern Cyprus.

Mughal, A.W. (2016). Investigating the impact of the Tier 4 policy on international students at private colleges in the UK. Journal of International Students, 6(1), 241-261. https://doi.org/10.32674/jis.v6i1.490

Nachatar Singh, J.K., Schapper, J., \& Jack, G. (2014). The importance of place for international students' choice of university: a case study at a Malaysian university. Journal of Studies in International Education, 18(5), 463-474. https://doi.org/10.1177/1028315314523990

Noble, H., \& Smith, J. (2015). Issues of validity and reliability in qualitative research. Evidence Based Nursing, 18(2), 34-35. https://doi.org/10.1136/eb-2015-102054

Nwaokugha, D.O., \& Ezeugwu, M.C. (2017). Corruption in the education industry in Nigeria: implications for national development. European Journal of Training and Development Studies, 4(1), 1-17.

OECD (2013). How is international student mobility shaping up? Education Indicators in Focus. https://doi.org/10.1787/5k43k8r4k821-en

OECD (2012). Assessment of higher education learning outcomes: feasibility study report, Volume $1 . \quad \underline{\text { http://www.oecd.org/education/skills-beyond- }}$ school/AHELOFSR eportVolume1.pdf

Olawore, O.P., \& Ajayi, T.B. (2016). The emergence of private universities in Nigeria and their various challenges. Journal of Applied Information Science and Technology, 9(1), 31-38.

Pimpa, N. (2004). The relationship between Thai students' choices of international education and their families. International Education Journal, 5(3), 352-359. 
Prakhov, I. (2016). The barriers of access to selective universities in Russia. Higher Education Quarterly, 70(2), 170-199. https://doi.org/10.1111/hequ.12087

Pyvis, D., \& Chapman, A. (2007). Why university students choose an international education: a case study in Malaysia. International Journal of Educational Development, 27, 235-246. https://doi.org/10.1016/j.ijedudev.2006.07.008

Ritchie, B.W. (2003). Managing educational tourism. Clevedon: Channel View.

Shanka, T., Quintal, V., \& Taylor, R. (2006). Factors influencing international students' choice of an education destination: a correspondence analysis. Journal of Marketing for Higher Education, 15(2), 31-46. https://doi.org/10.1300/j050v15n02 02

Soutar, G.N., \& Turner, J.P. (2002). Students' preferences for university: a conjoint analysis. International Journal of Educational Management, 16(1), 40-45. https://doi.org/10.1108/09513540210415523

SPO (2016). Economic and social indicators. TRNC State Planning Organization. http://www.devplan.org

TCYHB (2015). KKTC 2014 Ekonomi Durum Raporu Türkiye Cumhuriyeti Lefkoşa Büyükelçiliği. Lefkoşa, KKTC.

UNESCO. (2018). Nigeria. UNESCO Institute for Statistics. http://uis.unesco.org/country/NG

UNESCO (2009). Trends in global higher education: tracking an academic revolution. Paris: United Nations Educational, Scientific and Cultural Organization.

Vrontis, D., Thrassou, A., \& Melenthiou, Y. (2007). A contemporary higher education student-choice model for developed countries. Journal of Business Research, 60(9), 979-989. https://doi.org/10.1016/j.jbusres.2007.01.023

WENR (2018). Education in Nigeria. World Education News + Reviews, 7 March. http://wenr.wes.org/2017/03/education-in-nigeria

Wilkins, S., Balakrishnan, M.S., \& Huisman, J. (2012). Student choice in higher education: motivations for choosing to study at an international branch campus. Journal of Studies in International Education, 16(5), 413-433. https://doi.org/10.1177/1028315311429002

Wilkins, S., \& Huisman, J. (2011). International student destination choice: the influence of home campus experience on the decision to consider branch campuses. Journal of Marketing for Higher Education, 21(1), 61-83. https://doi.org/10.1080/08841241.2011.573592

Yang, M. (2007). What attracts mainland Chinese students to Australian higher education. Studies in Learning, Evaluation, Innovation and Development, 4(2), 1-12. 